\title{
U.S. Geological Survey Water-Resources Programs in New Mexico, FY 2015
}

The U.S. Geological Survey (USGS) is a Federal science agency that provides impartial information on the health of our ecosystems and environment, the natural hazards that threaten us, the natural resources we rely on, the impacts of climate and land-use change, and the core science systems that help us provide timely, relevant, and usable information.

\section{Water-Resources Programs in New Mexico}

The USGS has collected hydrologic information in New Mexico since 1889, beginning with the first USGS streamflow-gaging station in the Nation, located on the Rio Grande near Embudo, New Mexico. Water-resources information provided by the USGS is used by many government agencies for

- Issuing flood warnings to protect lives and reduce property damage,

- Managing water rights and interstate water use,

- Protecting water quality and regulating pollution discharges,

- Designing highways and bridges,

- Planning, designing, and operating reservoirs and watersupply facilities,

- Monitoring the availability of groundwater resources and forecasting aquifer response to human and environmental stressors, and

- Prioritizing areas where emergency erosion mitigation or other protective measures may be necessary after a wildfire.

For more than 100 years, the Cooperative Water Program has been a highly successful cost-sharing partnership between the USGS and water-resources agencies at the State, local, and tribal levels. It would be difficult to effectively accomplish the mission of the USGS without the contributions of the Cooperative Water Program.

\section{Selected USGS Partnerships in New Mexico}

Local

- Acoma, Navajo, and Zuni Indian Nations

- Navajo Nation Environmental Protection Agency

- Albuquerque Bernalillo County Water Utility Authority

- Buckman Direct Diversion Board

- Canadian River Municipal Water Authority

- Cities of Albuquerque, Las Cruces, Raton, Ruidoso, Santa Fe, and Santa Rosa
- Compact Commissions: Costilla Creek, Rio Grande, and Pecos River

- Counties of Bernalillo, Lea, Lincoln, Sandoval, and Santa Fe

- Elephant Butte Irrigation District

- La Cienega Acequia

- Los Alamos County Utilities

\section{State of New Mexico}

- Department of Agriculture

- Department of Homeland Security

- Department of Transportation

- Energy, Minerals, and Natural Resources Department

- Environment Department

- Interstate Stream Commission

- New Mexico State University

- New Mexico Water Resources Research Institute

- Office of the State Engineer

\section{State of Texas}

- Commission on Environmental Quality

- El Paso Water Utilities Service Board

\section{Federal}

- Army Corps of Engineers

- Bureau of Indian Affairs

- Bureau of Land Management

- Bureau of Reclamation

- Forest Service

- International Boundary and Water Commission

- Cannon Air Force Base

- Kirtland Air Force Base

- National Park Service

- Natural Resources Conservation Service

- White Sands Missile Range 


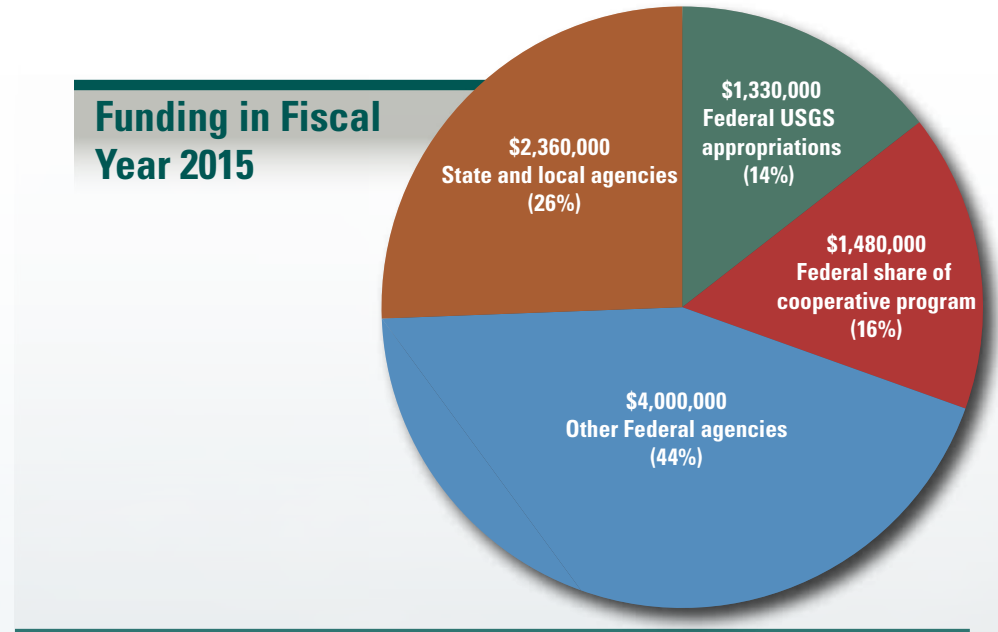

\section{New Mexico Water Science Center Activities, 2014-15}

- National Water Quality Assessment of the status of and trends in surface water and groundwater in selected areas of New Mexico and the natural and human factors affecting water quality. Cooperator: Federal Program of the USGS

- Determination of potential groundwater-flow pathways in the vicinity of the San Juan Mine near Farmington, N. Mex. Cooperators: Mining and Minerals Division of the New Mexico Energy, Minerals, and Natural Resources Department

- Collection and analysis of rainfall, discharge, and water-quality data in the storm drainage system of the Albuquerque metropolitan area. Cooperators: City of Albuquerque and Bernalillo County

- Analysis of the magnitude and frequency of peak flows and estimation of flow characteristics in unregulated streams throughout New Mexico. Cooperator: New Mexico Department of Transportation

- Characterization of the effects of groundwater withdrawals on streamflow and geochemistry of surface-water and groundwater systems in the Upper Hondo Basin, Lincoln County, N. Mex. Cooperator: Lincoln County

- Potential groundwater recharge from a domestic sewage disposal field and collection of precipitation, groundwater levels, and groundwaterquality data to improve the understanding of groundwater resources in eastern Bernalillo County, N. Mex. Cooperator: Bernalillo County

- Quantification of the magnitude of shallow groundwater flow between the Rio Grande and riverside drains at eight selected locations. Cooperator: Bureau of Reclamation

- Implementation of an interactive Web-based tool for quickly estimating streamflow statistics and obtaining basin characteristics for stream locations in New Mexico for use by Federal, State, and local agencies. Cooperators: New Mexico Department of Transportation and Forest Service

- Characterization of surface-water flow within the Upper Rio Grande Basin through development of a basin-wide water-operations model that can account for deliveries, use, and routing of different water sources to the Rio Grande and forecast different water-operation scenarios within the basin. Cooperators: Bureau of Reclamation and Army Corps of Engineers

- Real-time hydrologic monitoring of streamflow of approximately 160 stations for flood forecasting, State water compacts, and drought tracking. Cooperators: local, State, and Federal agencies

- Groundwater, sediment, precipitation, and water-quality data collection. Cooperators: local, State, and Federal agencies

- Refinement of a hydrologic simulation model to improve understanding in the Rio Grande transboundary area of New Mexico, Texas, and northern Mexico. Cooperator: Bureau of Reclamation

- WaterAlert precipitation and streamflow system after the Las Conchas, Whitewater-Baldy, and Little Bear fires in New Mexico. Cooperators: Natural Resources Conservation Service, New Mexico Department of Homeland Security, and Federal Program of the USGS
- Determination of the location, extent, and magnitude of landsurface subsidence in the Albuquerque metropolitan area by using interferometric synthetic aperture radar (insar) methods. Cooperator: Albuquerque Bernalillo County Water Utility Authority

- Comparison of estimated predevelopment runoff from the Albuquerque Basin with current urbanized runoff and potential for recharge to the groundwater system. Cooperator: Albuquerque Bernalillo County Water Utility Authority

- Investigation of groundwater and constituent pathways, aquifer delineation, and recharge characteristics at Fort Wingate Depot Activity, N. Mex. Cooperator: Army Corps of Engineers

- Development of a conceptual model of the hydrogeology and geochemistry of Many Devils Wash, at the Shiprock Disposal Site, N. Mex. Cooperator: Navajo Nation Environmental Protection Agency

- Delineation of zones of contribution and areas contributing recharge to supply wells potentially affected by the Kirtland Air Force Base Bulk Fuel Spill, Albuquerque, N. Mex. Cooperator: Kirtland Air Force Base

- Assessment of dissolved solids as a surrogate for salinity in surface water and groundwater of the Palomas, Mesilla, and Hueco Basins, New Mexico and Texas. Cooperator: New Mexico Environment Department

- Quantification of the volume of streamflow entering and leaving New Mexico and identification of areas where streamflow gains and losses occur. Cooperator: New Mexico Water Resources Research Institute

- Hydrogeologic assessment of Cannon Air Force Base and surrounding area with respect to groundwater-level conditions and direction of groundwater flow. Cooperator: Cannon Air Force Base

- Prewildfire assessment of the potential for postwildfire debris flows in the Jemez Mountains, north-central New Mexico. Cooperators: Forest Service, Albuquerque Bernalillo County Water Utility Authority, Buckman Direct Diversion Board, Army Corps of Engineers, and Los Alamos County Utilities

- Determination of the magnitude and frequency of debris flows and floods from extreme precipitation in September 2013, Gila National Forest. Cooperators: Forest Service, New Mexico Department of Homeland Security, and New Mexico Department of Transportation

\section{For additional information, please contact:}

David Mau

Director, New Mexico Water Science Center dpmau@usgs.gov http://nm.water.usgs.gov (505) 830-7901

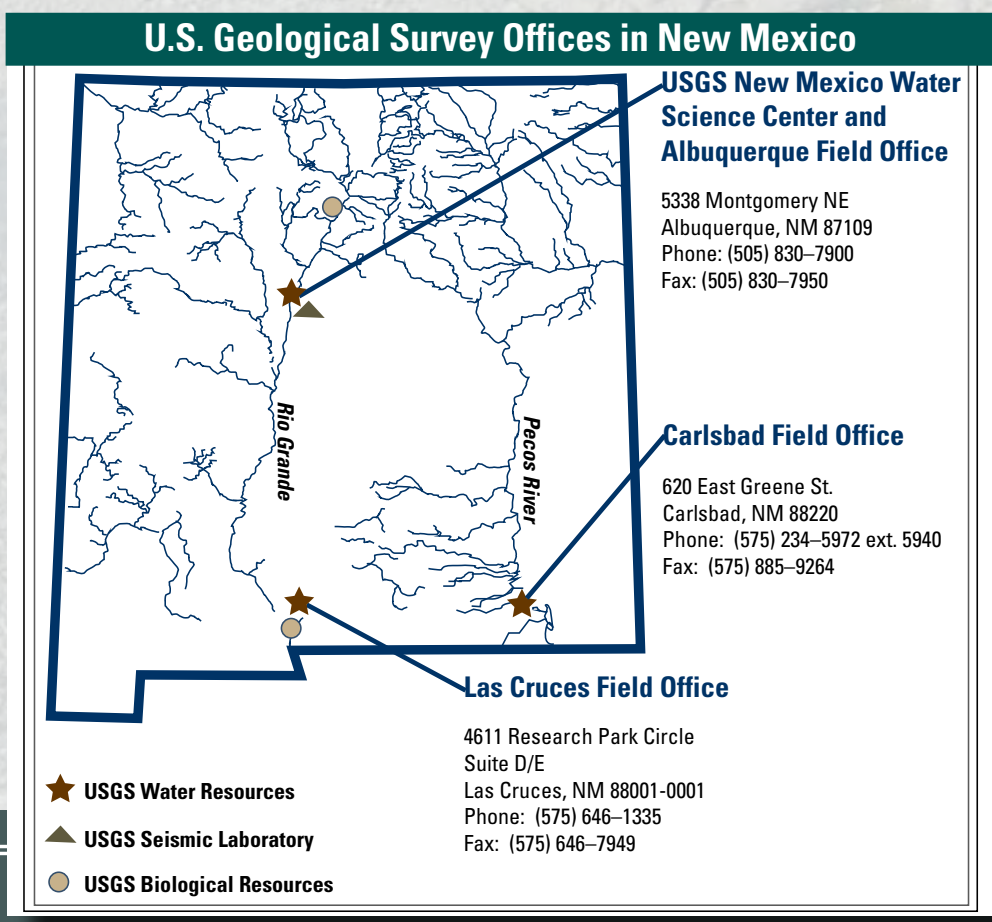

